DOI https://doi.org/10.18551/rjoas.2020-11.23

\title{
AUDITOR'S ABILITY TO DETECT FRAUD: INDEPENDENCE, AUDIT EXPERIENCE, PROFESSIONAL SKEPTICISM, AND WORK LOAD
}

\author{
Anto La Ode*, Hamid Wahyuniati, Florensia Angela, Supyati Oktri \\ Faculty of Economics and Business, Halu Oleo University, Kendari, Indonesia \\ *E-mail: laodeanto@gmail.com
}

\begin{abstract}
This study aims to determine and analyze the effect of independence, audit experience, professional skepticism, and workload on the auditor's ability to detect fraud. The sample in this study was all auditors at the Inspectorate of Southeast Sulawesi Province. The data collection method used a questionnaire which was distributed to the respondents. The data analysis method used multiple linear regression analysis. Based on the results of data analysis, it was found that independence had a positive and significant effect on the auditor's ability to detect fraud. Meanwhile, audit experience and professional skepticism do not have a significant effect on the auditor's ability to detect fraud. Meanwhile, workload has a negative and significant effect on the auditor's ability to detect fraud.
\end{abstract}

\section{KEY WORDS}

Auditor's ability to detect fraud, independence, audit experience, professional skepticism, workload.

The problem of fraud in the government sector is nothing new. This is evidenced by the existence of several frauds committed by government administrators in the presence of cooperation between the parties in power and their subordinates. Some of the frauds that are often found, such as, disappearance of documents, fictitious transactions, manipulation of financial statements that can harm state finances. Transparency International Indonesia in 2019 released the Corruption Perceptions Index (CPI) Indonesia is in 85th position out of 180 countries with a score of 40 from the highest score of 100 (www.transparency.org). The survey results show that the level of corruption in Indonesia is one of the countries with a fairly high level of corruption. To reduce the occurrence of fraud (corruption) in this country, an effective and efficient way is needed, therefore every government agency needs auditors to supervise and examine financial reports that have been prepared by management. External auditors become a medium for fraud detection. Likewise, internal auditors such as Government Internal Supervisory Apparatus such as the Development and Finance Audit Board and Provincial and District/City Inspectorates (ACFE, 2017). The inspectorate as the implementer of the internal audit of the local government becomes a pillar that serves as a supervisor as well as a guard in the implementation of government programs, which is required to prevent and detect the potential for fraud that can occur within the government environment (Waluyo, 2011).

One of the factors affecting the failure of auditors to detect fraud is technical competence which is constrained (Tuanakota, 2013). Technical competence is constrained due to the weak level of knowledge, experience and auditor independence (Koroy, 2009). Other factors that cause auditor failure are the low level of professional skepticism held by auditors (Carpenter et al., 2011) and excessive auditor workload (Nasution, et al., 2012).

Independence is an attitude and action in carrying out an examination to be impartial to anyone and not to be influenced by anyone. The higher the independence of the auditor, the more the auditor's ability to detect fraud will increase (Hartan, 2016). Professional skepticism is an attitude that includes a mind that is always questioning, being alert to conditions that can indicate possible misstatements, whether caused by fraud or error, and an important assessment of audit evidence. Supriyanto (2014) states that the higher the professional skepticism the auditor has, the more auditors are able to detect fraud. The workload of the auditor will also affect the ability of the auditor to detect fraud (Lopez and Peters, 2011). The 
workload related to the number of assignments can add to the experience of auditors in carrying out their audit duties so that it makes them more familiar and easier to detect fraud. An experienced auditor will find it easier to find indications of fraud and can also provide the right solution in handling fraud (Yulia and Nayang, 2018). An auditor with high flight hours and who is used to finding fraud may be more thorough in detecting fraud than an auditor with low flight hours (Anggriawan, 2014).

Research on the auditor's ability to detect fraud has been carried out by several researchers with inconsistent and contradictory results. Research conducted by Indrawati et al. (2019) and Widiyastuti (2009) stated that independence has a positive effect on the auditor's ability to detect fraud. However, research conducted by Sanjaya (2017) suggests a different matter, that independence has no effect on the auditor's ability to detect fraud. The ability of the auditor to detect fraud still exists even when performing audit procedures or seeking evidence that the auditor is unable to maintain his independence. Furthermore, research by Sihombing, et al. (2019), Suryanto, et al. (2017), Suryandari (2017), Yati (2017) and Suraida (2005) found that audit experience affects the auditor's ability to detect fraud. This is different from the research results of Larasati and Puspitasari (2019) which found that experience had no effect on the auditor's ability to detect fraud. Another phenomenon that attracted researchers to conduct this research was the finding of inconsistencies in the results of research on the effect of professional skepticism and workload on the auditor's ability to detect fraud. Research by Khomsiyah, et al. (2019), Sihombing, et al. (2019), Indrawati, et al. (2019), Fadhilah (2018), and Idawati (2018) found that professional skepticism has a positive and significant effect on the auditor's ability to detect fraud. These results are not in line with the results of research conducted by Suryanto et al. (2017) which found that professional skepticism has no effect on the auditor's ability to detect fraud. Furthermore, Fawdy's research (2017) found that auditors with a higher workload would reduce their skepticism and would not improve their ability to detect when facing symptoms of fraud, and auditors with more experience would improve their ability to detect when facing symptoms of fraud. Furthermore, Yulia and Nayang (2018) and Faradina (2016) find that there is a negative and significant direct relationship between workload and the ability of auditors to detect fraud. These results are not in line with the research results of Suryanto, et al. (2017), Suryandari (2017), Yati (2017), and Larasati and Puspitasari (2019) who found that workload has no effect on auditors' ability to detect fraud.

Based on the research gap mentioned above, this study tries to fill the gaps in previous research. This research is also a development of research that has been conducted by several previous researchers who examined the factors that affect the ability of auditors to detect fraud, which suggests further analysis of strengthening independence, audit experience, and professional skepticism and setting the workload of auditors so that their auditor's ability in detecting fraud can be better.

\section{LITERATURE REVIEW}

Theory of Planned Behavior. Theory of planned behavior (TPB) is a development of the theory of reasoned action (TRA) by adding a construct, namely perceived behavior control. This construct is added in TPB to control individual behavior which is limited by its shortcomings and limitations from the lack of resources used to carry out the behavior (Jogiyanto, 2007: 61). The theory of planned behavior assumes that humans will usually behave appropriately in accordance with what their environment wants. The purpose and benefits of this theory in the context of this research is to predict and understand the motivational influences of behavior, both the individual's will and not the will of the individual (Ajzen, 1991). The theory of planned behavior has a function of three basic determinants. First, related to one's basic attitudes, for example, one's attitude towards intuition, other people, or objects. This theory can explain that the basic attitude or personality of a person can be formed on the person's response to the environment, objects, and intuition. Also related to this research, the auditor's skepticism is an attitude in dealing with a given case or audit assignment. In addition, the amount of workload, in this case the workload or audit 
burden borne by a person, will also affect how he will behave. Second, describing the social influences called subjective norms. Third, related to control issues. This factor is related to the past and a person's perception of how difficult it is to carry out a behavior, for example, the audit experience in carrying out audit procedures in an audit assignment (Januarti, 2011).

Auditor Ability to Detect Fraud. Fraud according to Sudarmo (2009) is that there are at least three fundamental elements in cheating, namely: (1) fraud is committed by someone on purpose, (2) fraud is in the form of concealing facts or fraud or coercion, and (3) fraud aims to gain benefits specific party. Meanwhile, according to Karyono (2013), fraud is an action that is carried out on purpose and results in material misstatement in the financial statements where this financial report is the main subject in the audit. There are four factors driving someone to commit fraud, namely: 1) Greed is related to potential greedy behavior in everyone, 2) Opportunity is related to the state of the organization, agency, society in such a way that it is open for someone to commit fraud against them, 3) Need is related to the factors needed by the individual to support his life properly, and 4) Exposure is related to the possibility of being exposed to a fraud and the nature and severity of punishment for the perpetrator of fraud.

According to Karyono (2013), fraud consists of several types, namely: 1) Fraudulent Financial Reporting, namely a statement of error or error from the amount or disclosure with the aim of deceiving users, 2) Misapropriation of Asset, namely fraud involving theft of a unit of assets, 3 ) Corruption is the most difficult fraud to detect because it involves cooperation with other parties, and 4) Computer-related fraud is a type of time crime that is grouped into computer destruction, theft of information and assets, financial fraud or cash theft and the sale of computer services online invalid.

Fraud can be detected not only through the audit process by a public accountant but more comprehensively through the fraud detection cycle that involves management, internal auditors, external auditors and forensic auditors. The auditor's ability to detect fraud is the quality of an auditor in explaining the impropriety of the financial statements presented by the company by identifying and proving the fraud (Sudarmo, 2009). Fraud detection is an action to find out that fraud occurred, who was the perpetrator, who was the victim and what was the cause. The key to fraud detection is to be able to see if there are errors and irregularities. The ability to detect fraud means the process of discovering or determining an illegal act that could result in deliberate misstatement in financial reporting. Mui (2010) states that the task of detecting fraud is an unstructured task that requires auditors to produce alternative methods and seek additional information from various sources. Koroy (2009) states that fraud detection is not an easy task to be carried out by auditors, it requires the ability to quickly identify and identify the potential and causes of fraud with assessment indicators including characteristics of the occurrence of fraud, auditing standards, internal control systems, and documentation testing.

Independence. The attitude of independence for a public accountant means that he is not easily influenced because he carries out his work for the public interest. Therefore, he is not allowed to take sides with anyone, because no matter how perfect his technical skills are, he will lose the impartiality that is so necessary to defend his freedom of opinion. Independence is an attitude and action in carrying out an examination not to be impartial and to be seen as impartial to anyone, and not to be influenced and to be seen as not being influenced by anyone. The auditor intellectually must be honest, free from obligations to his clients and have no interest with the client, both management and owners.

According to Mulyadi (2016), in reality accountants often have difficulty maintaining their independent mental attitude. Conditions that often interfere with the independent mental attitude of an auditor, namely: 1) As a person who carries out an independent examination, the accountant is paid by his client, 2) As a salesperson, an accountant has a tendency to satisfy the desires of his client, and 3) Maintaining an independent mental attitude often can causing client abandonment.

Auditor independence can be measured by three indicators (Agoes, 2017: 60-61), namely as follows: 1) Independent In Appearance; In appearance the public accountant is independent because he is a party outside the company, 2) Independent In Fact; In Fact, 
public accountants should be independent, as long as they carry out their duties to provide professional services, be able to maintain integrity and always comply with the code of ethics, the public accounting profession and the professional standards of public accountants. If not so, in-fact public accountants are not independent, and 3) Independent in Mind; For example, an auditor may obtain audit findings that indicate violations or corruption or which require a material audit adjustment. Then he thought about using the audit findings to black out the auditee. Even though it has just been thought about, it hasn't been implemented, the auditors in mind have lost their independence. This applies to both public accountants and internal auditors.

Audit Experience. Audit experience is the experience of auditors in examining financial statements in terms of both the length of time and the number of engagements that have been performed. Experience is very important in terms of an examiner's obligation to fulfill his/her duties to meet audit standards. The more experience an auditor has, the more appropriate the consideration of the level of materiality in the financial statements will be. In addition, the higher the level of experience of an auditor, the better the views and responses to the information contained in the financial statements, because the auditors have done a lot of their duties or have examined the financial statements a lot (Novanda, 2012). Experience will shape one's competence and expertise both technically and psychologically. According to Arens et al. (2010), competency means that an auditor must have the qualifications to understand the criteria used and must be competent to know the type or amount of evidence that will be collected in order to reach the right conclusion after examining the evidence.

An employee who has high work experience will have advantages in several ways including detecting errors, understanding errors and looking for causes of errors. Various kinds of experiences that individuals have will affect the implementation of a task. An auditor must have experience in auditing activities; formal education and work experience in the accounting profession are two important and complementary things (Mulyadi, 2016). The government requires at least three years of work experience as a reputable accountant in the audit sector for accountants who wish to obtain a license to practice in the public accounting profession. Good assessments are those carried out objectively by people who are expert (competent) and careful (due care) in carrying out their duties. To ensure the objectivity of the assessment, the auditors (auditors) both personally and institutionally must be independent from the audited party (auditee), and to ensure their competence, an auditor must have expertise in auditing and have sufficient knowledge of the area being audited. Meanwhile, accuracy in carrying out tasks is shown by good planning, implementation of activities according to standards and code of ethics, active supervision of the personnel used in assignments, and so on (Rinaldi, 2015). Some of the qualitative characteristics of an auditor include: 1) Competence means that the auditor must have expertise in the field of auditing and have sufficient knowledge of the field being audited, 2) Objective means being straightforward to the management responsible for preparing the report and to the users of the report 3) Accuracy in carrying out their duties, namely in carrying out their duties, auditors must use their expertise carefully (due professional care), plan well, use an appropriate approach, and provide opinions based on sufficient evidence and be studied in depth.

Professional Skepticism. The Indonesian Government Internal Audit Standard (2013: 18) defines professional skepticism as an attitude that includes a mind that always questions and critically tests audit evidence. Auditors are expected to use skepticism in conducting audits, and in gathering sufficient evidence to support or refute management's statements. Professional skepticism means that the examiner does not think that the responsible party is dishonest, but also does not think that the honesty of the responsible party is unquestionable.

Gusti and Ali (2008) argue that professional skepticism is influenced by: 1) ethical bias factors, 2) situation factors, and 3) assignment factors. Furthermore, Fullerton and Durtschi (2004) suggest three main characteristics that a person has when applying professional skepticism, namely: 1) Characteristics related to testing audit evidence. A questioning mindset is a character of someone's skepticism in questioning reasons, adjustments and proving an object. Seeking knowledge is a character of someone's skepticism which is based 
on curiosity. 2) Characteristics related to understanding audit evidence. Interpersonal understanding is the character of someone's skepticism which is formed from understanding the purpose, motivation and integrity of an information provider. Confidence is a character of someone's skepticism to be confident professionally in acting on the evidence that has been collected. Persistence is the character of someone's skepticism in objectively concluding the evidence that has been collected.

Professional skepticism can be measured by three indicators (Hurt, 2010), namely: 1) Examining and testing evidence; The mind is always wondering, namely characteristics that question reasons, adjustments, and proof of something, Suspension and judgment are characteristics that indicate a person needs a long time to make careful considerations and add additional information to support these considerations, Knowledge search is a characteristic that based on high curiosity, 2) Understanding the information provider; Interpersonal understanding is someone's skeptical character formed from understanding goals, motivation, and integrity and information providers, 3) Taking action on evidence; Selfconfidence, namely confident in a professional manner to act on the evidence that has been collected, Self-determination, namely the attitude of a person to objectively conclude that has been collected both positive and negative effects.

Auditor Workload. Workload is one aspect of increasing organizational productivity and the quality of services produced. Therefore, the workload must be in accordance with its capacity and considered by every organization so that activities can run effectively and efficiently and the resulting services are of quality. Workload shows the workload faced by an auditor. So, workload is the amount of work that must be done within a predetermined time (Setiawan and Fitriany, 2011). Meanwhile, the definition of workload according to Pranoto and Retnowati (2015) is an action that aims to determine the amount of time an employee takes to complete a job. According to Kurnia (2010), the definition of workload, which is a process of analyzing the time used by a person or group of people in completing the tasks of a job (position) or group of positions (work unit) carried out in normal circumstances or conditions.

Munandar (2010), classifies workload into intrinsic factors in work, namely physical demands and task demands. The workload can be divided into three categories, namely: 1) Too much/little "Quantitative" workload that arises as a result of too many/few assignments given to workers to be completed within a certain time, 2) Excessive/too little workload "Qualitative" that is if people feel unable to carry out a task or carry out a task they do not use the skills and/or potential of the workforce, and 3) Too little workload can cause a lack of stimulation which will lead to low enthusiasm and motivation to work, because employees will feels that he is not advancing and feels powerless to show his talents and skills.

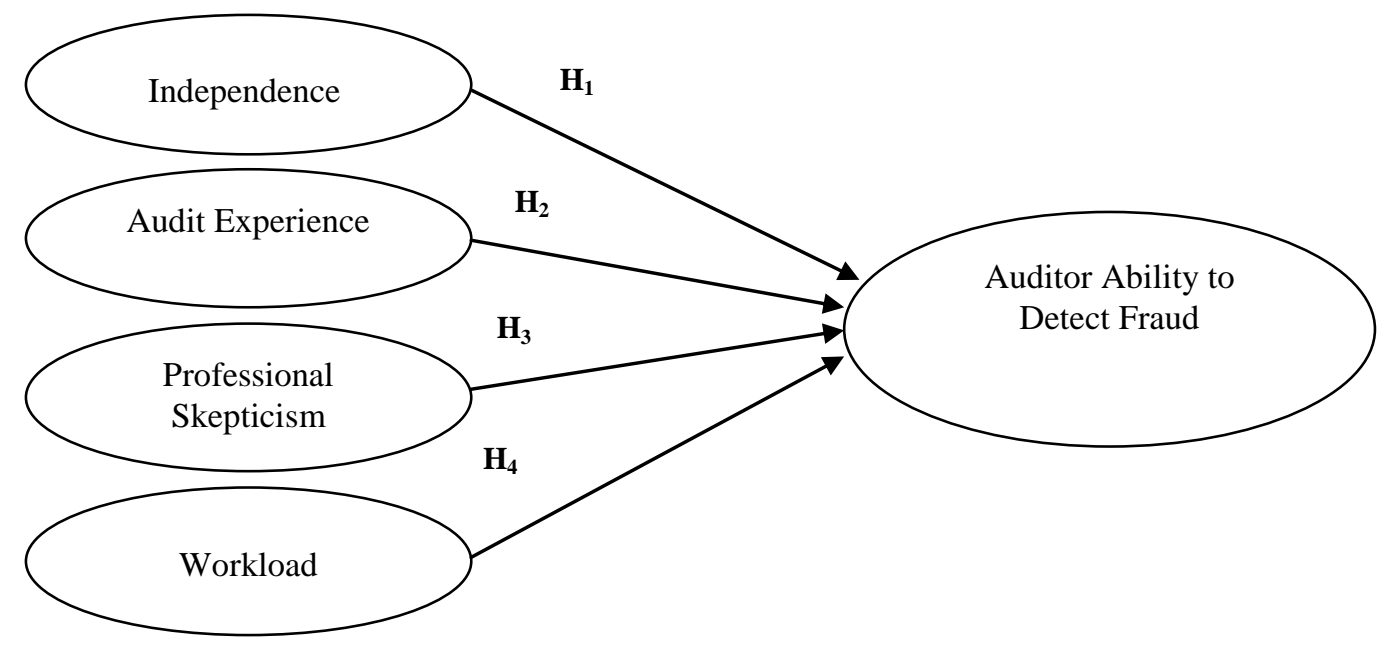

Figure 1 - Conceptual Framework 
Measurement of workload can be carried out in various procedures, however Muskamal (2010) has broadly classified three categories of workload measurements, namely: 1) subjective measurement, 2) performance measurement, and 3) physiological measurement. The factors that affect the workload according to Soleman (2011) are: 1) External factors, namely the burden that comes from outside the worker's body, such as: number of assignments, work organization, and work environment, 2) Internal factors, namely factors originating from within the body the result of reactions to external workloads that are potential stressors, including somatic factors (gender, age, body size, nutritional status, health conditions, etc.), and psychological factors (motivation, perception, belief, desire, satisfaction, etc.).

Based on theoretical studies and empirical studies, independence, audit experience, professional skepticism, workload can affect the ability of auditors to detect fraud. Thus, the conceptual framework of this research can be presented in the Figure 1.

Research Hypothesis. Independence is an impartial attitude or an attitude free from any influence in auditing financial statements. An attitude of independence can also be called a neutral attitude and is not influenced by any party. An independent attitude is needed by the auditor to be free from the interests and pressure of any party, so that fraud in the object being audited can be detected appropriately (Fitri, 2015). Research conducted by Indrawati et al. (2019) states that independence has a positive effect on the ability of auditors to detect fraud. This influence is indicated by the higher the independence of an auditor, so it can increase his ability to detect fraud. This research is supported by Sanjaya (2017) and Hartan (2016) which state that independence has a positive and significant effect on the ability of auditors to detect fraud, which indicates that the higher the independence of an auditor, it can increase his ability to detect fraud. fraud.

$\mathrm{H1}$ : Independence has a positive and significant effect on the auditor's ability to detect

Auditors who have a lot of experience can find out more about various audit problems, besides that it will be easier for auditors to keep up with increasingly complex developments. So that the amount of experience the auditor has can affect his level of ability to carry out audits. This explanation shows that the amount of audit experience will have an effect on increasing the ability of auditors to detect fraud, because a lot of audit experience makes auditors more thorough. Anggriawan (2014) said that experience will provide lessons on the types of fraud that the auditor has found. Experienced auditors keep many things in their memory so that they can develop a good understanding of the case at hand. This statement is supported by research by Sihombing, et al. (2019), Suryanto, et al. (2017), Suryandari and Yuesti (2017) and Yati (2017), Nasution, et al (2012), and Hasanah (2010) who found that with a lot of auditor experience will increase the auditor's ability to detect fraud. So, it can be concluded that the more experience an auditor gains, it will make it easier for the auditor to detect fraud found during the audit process.

H2: Audit experience has a positive and significant effect on the auditor's ability to detect fraud.

Professional skepticism is the attitude of an auditor by always questioning and critically evaluating existing audit evidence. Fullerton and Durtschi (2004) state that auditors need professional skepticism in order to detect fraud. Because when the auditor's professional skepticism is low, auditors tend to ignore the symptoms of fraud. If the auditor's professional skepticism is high, the possibility of undetected fraud will be smaller. Research conducted by Prasetyo (2015) states that professional skepticism affects the ability of auditors to detect fraud, and indicates that the higher the professional skepticism an auditor has, the higher an auditor's ability to detect fraud. With the professional skepticism an auditor has in his audit assignment, it can make his ability to detect fraud better. This is in line with research by Khomsiyah et al. (2019), Adnan and Kiswanto (2017), and Hartan (2016) who found that the higher the professional skepticism the auditor has, the higher the auditor's ability to detect fraud.

H3: Professional skepticism has a positive and significant effect on the auditor's ability to detect fraud. 
The high workload of an auditor will have an effect on reducing the ability to detect fraud, because the high workload will make the auditor less sensitive. Setiawan and Fitriany (2011) state that high workloads will cause fatigue and dysfuncional behavior, thereby reducing their ability to find fraud. However, if the workload of the auditors is low, the auditors will have more time to evaluate the evidence found, so that the auditor can improve his ability to detect fraud. Thus, it can be said that a high workload will reduce the level of the auditor's ability to detect fraud (Fawdy, 2017; Munandar, 2010). fraud.

H4: Workload has a negative and significant effect on the auditor's ability to detect

\section{METHODS OF RESEARCH}

The population in this study is the Functional Position of Auditor and Supervisor of Local Government Affairs at the Inspectorate of Southeast Sulawesi Province. The sampling technique used was Saturated Sampling (Census). The type of data used is primary data with a Likert scale. The data collection technique used is by distributing questionnaires followed by conducting interviews and documentation. To determine the characteristics of respondents and descriptions of the indicators for each research variable, the descriptive analysis method was used. Furthermore, to test the research hypothesis used inferential analysis tools, namely multiple linear regression with the SPSS version 22 program.

\section{RESULTS OF STUDY}

Description of Research Variables. The independence variable in this study was measured using 10 statement items from 3 indicators which included independent in fact, independent in appearance, and independent in mind. The respondent's statement on the independence variable with a mean perception value of 3.85 is in the good category, and the independent in mind indicator gets stronger attention than independent in fact and independent in appearance. The independent in mind indicator is in the good category with a mean value of 4.05 , the independent in fact indicator with a mean value of 3.82 , and independent in appearance with a mean value of 3.69 .

The audit experience variable is measured using 13 statement items from 3 indicators including competence, objectivity, and work environment. The respondent's statement on the audit experience variable with a mean perception value of 3.94 is in the good category, and the competency indicator gets stronger attention than the objectivity and accuracy indicators. Competency indicators are included in the good category with a mean value of 3.95, objectivity indicators with a mean value of 3.94 , and accuracy indicators with a mean value of 3.94 .

The variable of professional skepticism in this study is measured using 15 item statements from 3 indicators which include examining and testing evidence, understanding information providers, and taking action on evidence. Respondents' statements on the variable professional skepticism with a mean perception value of 4.05 are in the good category, and the indicators of examining and testing evidence get stronger attention than indicators of understanding information providers and indicators of taking action on evidence. The indicator of examining and testing evidence is included in the good category with a mean value of 4.07 , the indicator understands information providers with a mean value of 4.04 , and the indicator takes action on the evidence with a mean value of 4.05 .

The workload variable in this study is measured using 18 item statements from 4 indicators which include the number of assignments, work organization, work environment, and worker conditions. The respondent's statement on the workload variable with a mean perception value of 3.86 is in the good category, and the indicators of the number of assignments get stronger attention than indicators of work organization, worker environment, and worker conditions. The number of assignment indicators is in the good category with a mean value of 3.90 , the worker condition indicator with a mean value of 3.88 , the work 
environment indicator with a mean value of 3.85 , and the work organization indicator with a mean value of 3.81 .

The variable of the auditor's ability to detect fraud is measured by using 20 statement items from 4 indicators including the characteristics of fraud, auditing standards, internal control systems, and documentation testing. The respondent's statement on the variable of the auditor's ability to detect fraud with a mean perception value of 4.13 is in the good category. The auditing standard indicator received stronger attention than the fraud characteristic indicator, the internal control system, and the documentation test. Auditing standard indicators are included in the good category with a mean value of 4.18, documentation test indicators with a mean value of 4.16 , internal control system indicators with a mean value of 4.14, and fraud characteristics indicators with a mean value of 4.07.

Hypothesis Testing. The results of multiple linear regression analysis are as shown in the following table.

Table 1 - Results of Multiple Linear Regression Analysis

\begin{tabular}{|c|c|c|c|c|c|}
\hline \multirow{2}{*}{ Model } & \multicolumn{2}{|c|}{ Unstandardized Coefficients } & \multirow{2}{*}{\begin{tabular}{|l} 
Standardized Coefficients \\
Beta
\end{tabular}} & \multirow[b]{2}{*}{$\mathrm{T}$} & \multirow[b]{2}{*}{ Sig. } \\
\hline & $B$ & Std. Error & & & \\
\hline \begin{tabular}{l|l}
1 & (Constant) \\
\end{tabular} & 55.982 & 15.752 & & 3.554 & .001 \\
\hline Independence $\left(\mathrm{X}_{1}\right)$ & .736 & .355 & .452 & 2.076 & .046 \\
\hline Audit Experience $\left(X_{2}\right)$ & .030 & .282 & .024 & .105 & .917 \\
\hline Professional Skepticism $\left(\mathrm{X}_{3}\right)$ & .119 & .198 & .102 & .601 & .552 \\
\hline Workload $\left(\mathrm{X}_{4}\right)$ & -.320 & .146 & -.365 & -2.189 & .036 \\
\hline Correlation $(\mathrm{R})$ & .728 & & & & \\
\hline Coefficient of Determination (R square) & .529 & & & & \\
\hline$F_{\text {-count }}$ & 9.563 & & & & \\
\hline Sig. (F) & .000 & & & & \\
\hline
\end{tabular}

Source: Data processed in 2020.

Based on the results of the analysis, the multiple linear regression equation is obtained as follows:

$$
Y=0.452 X 1+0.024 X 2+0.102 X 3-0.365 X 4
$$

The multiple linear regression equation model can be interpreted as follows:

- The value of the independence regression coefficient (X1) is 0.452 . This shows that there is a positive influence where if the independence variable has increased, the auditor's ability to detect fraud $(Y)$ will be better;

- The regression coefficient value of audit experience (X2) is 0.024 . This shows that there is a positive influence where if the audit experience variable increases, the auditor's ability to detect fraud $(\mathrm{Y})$ will be better;

- The regression coefficient value for professional skepticism (X3) is 0.102 . This shows that there is a positive influence where if the variable professional skepticism has increased, the auditor's ability to detect fraud $(\mathrm{Y})$ will be better;

- Workload regression coefficient value $(X 4)$ is -0.365 . This shows that there is a negative effect where if the workload variable increases, the auditor's ability to detect fraud $(Y)$ will decrease.

Based on the test results show that:

- Independence (X1) partially has a significant effect on the ability of auditors to detect fraud $(Y)$. This is indicated by the results of the t test at the sigf level. $0.046<\alpha=0.05$. Thus, $\mathrm{H} 1$ is accepted;

- Audit experience (X2) partially does not have a significant effect on the ability of auditors to detect fraud $(Y)$. This is indicated by the results of the t test at the sigf level. 0.917> $\alpha=0.05$. Thus, $\mathrm{H} 2$ is rejected; 
- Professional skepticism (X3) partially does not have a significant effect on the ability of auditors to detect fraud $(Y)$. This is indicated by the results of the test at the sigf level. 0.552> $\alpha=0.05$. Thus, $\mathrm{H} 3$ is rejected;

- Workload (X4) partially has a significant effect on the ability of auditors to detect fraud $(Y)$. This is indicated by the results of the t test at the sigf level. $0.036<\alpha=0.05$. Thus, $\mathrm{H} 4$ is accepted.

Multiple correlation coefficients for the variable independence (X1), audit experience (X2), professional skepticism (X3), workload (X4) and the ability of auditors to detect fraud $(Y)$ of $(R)=0.728$. Thus, the four variables simultaneously have a strong relationship to the ability of auditors to detect fraud. The coefficient of determination ( $R$ square) $=0.529$ or $52.9 \%$. This shows that the contribution of variables that affect taxpayer compliance is $52.90 \%$, while the rest $(47.10 \%)$ is influenced by other variables not included in this analysis.

\section{DISCUSSION OF RESULTS}

Effect of Independence on the ability of auditors to detect fraud. The results of this study indicate that independence has a positive and significant effect on the ability of auditors to detect fraud. This explains that the higher the independence of the auditor, the higher the auditor's ability to detect fraud. The independence of an auditor greatly affects his work results in detecting fraud that occurs. The attitude of independence in mind, in the organizational structure, and in carrying out its duties must comply with the standard provisions concerning the professional independence of auditors which will make it easier for auditors to detect fraud. The independency indicator in mind is the most dominant item in the independence variable. In carrying out their duties as auditors by applying an attitude of independence in mind, it can help them to maintain their independence where they must state audit findings without pressure from various parties. The attitude of independence in the organizational structure they have, of course, this attitude is always based on principles and ethics that they must obey. In implementing this attitude, of course it is not easy for auditors because they always meet co-workers who they know, be they friends or family, but they always try to maintain the independence they have by always obeying their principles and ethics as auditors so that they can avoid everything that happens can affect the independence they have. This means that as auditors they must maintain their independence in the engagement process by adhering to the principles and ethics of being an auditor. As an auditor, by implementing an independent attitude in carrying out their duties, of course, that is a way to maintain the independence they have. In the audit process carried out by the auditor, of course, it must be free from personal interests and from client interference that can interfere with the independence of the auditor. In carrying out their duties, the auditors always maintain the independence they have by focusing on audit procedures, so that tasks can be completed as expected. The results of this study are consistent with research conducted by Indrawati, et al. (2019) and Hartan (2016) which show that auditor independence has a significant effect on the ability of auditors to detect fraud. The results of this study are also in line with the results of the research of Sanjaya (2017), Wiguna (2015), Adnyani, et al (2014), and Widiyastuti (2009) which concluded that auditor independence has a positive and significant effect on the ability of auditors to detect fraud.

Effect of audit experience on the ability of auditors to detect fraud. The results of this study indicate that the audit experience has a positive but insignificant effect on the ability of auditors to detect fraud. Experience should provide lessons on the types of fraud that the auditor has discovered. Experienced auditors keep many things in their memory so that they can develop a good understanding of the case at hand. Auditors who have different experiences will also differ in viewing and responding to information obtained during the examination and also in providing audit conclusions on the object being examined. The results of this study are inconsistent with the results of research conducted by Sihombing, et al. (2019), Suryanto, et al. (2017), Suryandari and Yuesti (2017) and Yati (2017) who found that audit experience has a significant effect on the ability of auditors to detect fraud. The more experience an auditor gains, the easier it will be for the auditor to detect fraud during 
the audit process. Furthermore, Fawdy (2017) found that audit experience has a significant effect on the ability to detect it when facing fraud symptoms and auditors with more experience will increase the ability to detect it when facing symptoms of fraud. The results of research by Nasution, et al. (2012), Novanda (2012), and Hasanah (2010) also found that having a lot of experience in the auditor will increase the auditor's ability to detect fraud. However, the results of this study are in line with the research results of Larasati and Puspitasari (2019), Novita (2015), and Supriyanto (2014) who found that experience does not have a significant effect on the ability of auditors to detect fraud because the ability of auditors to detect fraud depends on the perpetrator's calling. fraud, frequency of manipulation, degree of collusion, and measure of seniority involved. The higher the level of collusion and the higher the level of management involved in fraud, the more difficult it will be to detect fraud by the auditor, so that in such conditions, the audit experience does not make a major contribution to the auditor in detecting such fraud.

Effect of professional skepticism on the ability of auditors to detect fraud. The results of this study indicate that the effect of professional skepticism has a positive but insignificant effect on the ability of auditors to detect fraud. Auditors who have a skeptical attitude should be more likely to find fraud because they do not easily believe the evidence and perform critical evaluations of the adequacy and relevance of audit evidence and information. The attitude of examining and testing evidence certainly requires a careful attitude in analyzing the evidence provided, which as the auditor must continue to question if there is something wrong with the evidence. Auditors tend not to accept explanations from clients without first considering them and attempt to resolve inconsistent information obtained from information providers. The Indonesian Government Internal Audit Standard (2013: 18) defines professional skepticism as an attitude that includes a mind that always questions and critically tests audit evidence. Because evidence is gathered and tested during the audit process, professional skepticism must be exercised during the process. The results of this study are inconsistent with research conducted by Indrawawti, et al. (2019), Khomsiyah, et al (2019), Sihombing, et al (2019), Said and Munandar (2018), Idawati (2018), Fadhilah (2018), Adnan and Kiswanto (2017), Prasetyo (2015) and Anggriawan (2014) ), Kushasyandita and Januarti (2012), Nasution, et al (2012), Carpenter et al. (2011), Noviyanti (2008), and Suraida (2006) which show that the professional skepticism of auditors has a positive and significant effect on the ability of auditors to detect fraud. However, the results of this study are in line with the results of research by Suryanto et al. (2017) which found that professional skepticism has no significant effect on the ability of auditors to detect fraud. This is related to several reasons, namely: first, the auditor has the responsibility and function of an independent auditor, so that auditors will try to fulfill their responsibilities and functions by referring more to audit standards and tend to ignore professional skepticism. In the context of this study, it was found that there was a tendency for auditors to try to complete their duties in accordance with existing regulations rather than actually carrying out examinations with the aim of detecting fraud. Second, the possible reason for the insignificant effect of professional skepticism on the ability of auditors to detect fraud could be due to the fixation of auditors' perceptions (Dearman and Shields, 2005; Luft and Shields, 2001). The point is that auditors tend to judge well on auditees who are actually their own peers and have been audited several times with good opinions. The next impact is that the auditor will experience a decrease in skepticism because of the good perception of the auditee.

Effect of workload on the ability of auditors to detect fraud. The results of this study indicate that workload has a negative and significant effect on the ability of auditors to detect fraud. The results of this study are consistent with research conducted by Molina and Safitri (2018), Nasution and Fitriyani (2012) who found that workload negatively affects the ability of auditors to detect fraud. The high workload will cause fatigue and dysfuncional behavior, thereby reducing his ability to find fraud. If the workload of the auditors is low, the auditors will have more time to evaluate the evidence found, so that the auditors can improve their ability to detect fraud (Setiawan and Fitriany, 2011). The results of this study also support the research conducted by Fawdy (2017) where the results of his research show that auditors with a higher workload will reduce their skepticism and will not improve their ability to detect 
when facing symptoms of fraud. In fact, a high workload will reduce the accuracy of auditors in carrying out audits. Thus, it can be said that a high workload will reduce the level of the auditor's ability to detect fraud. Vice versa, adequate workload will make auditors calm and comfortable in carrying out their duties, so that auditors can work more focused. Workload is one aspect of increasing organizational productivity and the quality of services produced, therefore the workload must be in accordance with its capacity and be considered by every organization so that activities can run effectively and efficiently and the resulting services are of quality. Workload shows the work load faced by an auditor. So, workload is the amount of work that must be done within a predetermined time (Setiawan and Fitriany, 2011). If workload is linked to the intrinsic factor, it can be said that the workload carried out by an employee will indirectly result in optimal work performance besides its impact on employee performance, physical conditions also have an impact on the mental health of a workforce. Employees who are given a work load means that the employee is recognized by the leadership, so that the employee will be more responsible for carrying out duties professionally and forming the accuracy, skill, and skill of an auditor to detect fraud during the examination process (Munandar, 2010). The results of this study are different from the results of research by Sihombing, et al. (2019), Faradina (2016), and Novita (2015) which found that workload has a negative but insignificant effect. Likewise, the research results of Suryanto (2017), Suryandari and Yuesti (2017), and Yati (2017) show that workload does not affect the ability of auditors to detect fraud.

\section{CONCLUSION AND RECOMMENDATIONS}

Based on the problems, objectives, results of the analysis and discussion in this study, several conclusions can be drawn as follows: 1 . Independence has a positive and significant effect on the ability of auditors to detect fraud, meaning that the higher the independence, the higher the auditor's ability to detect fraud. 2. Audit experience has a positive but insignificant effect on the auditor's ability to detect fraud, meaning that the audit experience is considered not to significantly influence the auditor in detecting fraud. 3. Professional skepticism has a positive but insignificant effect on the ability of auditors to detect fraud, meaning that professional skepticism does not significantly affect auditors in detecting fraud. 4. Workload has a negative and significant effect on the ability of auditors to detect fraud, meaning that the higher the workload, it will cause fatigue, thereby reducing their ability to detect fraud.

Based on the results of the discussion that has been concluded in this study, the author's suggestions are as follows: 1 . The government should continuously improve auditor independence and regulate an appropriate workload in order to avoid excessive workloads so that auditors can maintain and even improve their ability to detect fraud. Likewise, it is important for the government to improve the experience of auditors so that they have the ability to detect fraud well and constantly remind auditors of their professional skepticism, 2 . This research was only conducted at the Inspectorate of Southeast Sulawesi Province so that its generalization ability is still quite weak and only measures four independent variables, and uses a quantitative approach with a questionnaire so there is a possibility of bias. For further research, it is necessary to expand the scope of the research sample and add other variables, and can use a qualitative approach in order to obtain a more comprehensive understanding.

\section{REFERENCES}

1. Adnan, J. and Kiswanto. 2017. Determinant of Auditor Ability to Detect Fraud with Professional Scepticism as A Mediator Variable. Accounting Analysis Journal, 6 (3), pp. 313-325.

2. Adnyani, N., Atmadja A.T. and Herawati N.T. 2014. The Influence of Auditor's Professional Skepticism, Independence, and Auditor's Experience on Auditor's Responsibility in Detecting Fraud and Errors in Financial Statements (Case Study on Public Accounting Firm (KAP) Bali Region). Undiksha Journal. 
3. Agoes, S. 2017. Auditing. Edition 4. Jakarta: Salemba Empat.

4. Ajzen, I. 1991. The Theory of Planned Behavior. Organizational Behavior and Human Decision Processes, 50 (2), pp. 179-211.

5. Anggriawan, E. F. 2014. The Influence of Workload, Professional Skepticism and Time Pressure on the Auditor's Ability to Detect Fraud. Nominal Journal, III (2), pp. 101-116.

6. Arens, A., Randal, J. E., and Beasley, M. S. 2010. Auditing and Assurance Services: An Integrated Approach. Volume 2, Edition 12. Jakarta: Erlangga.

7. Association Certified Fraud Examiner (ACFE). 2017. Fraud Indonesia Survey 2016. Jakarta: ACFE Indonesia Chapter.

8. Carpenter, T. D., Durtschi, C. and Gaynor, L. M. 2011. The Incremental Benefit of a Forensic Accounting Course on Skepticism and Fraud-Related Judgments. Issues in Accounting Education, 26 (1), pp. 1-21.

9. Dearman, D.T. and Shields, M.D. 2005. Avoiding Accounting Fixation: Determinants of Cognitive Adaptation to Differences in Accounting Method. Contemporary Accountinig Research, 22 (2), pp. 351-384.

10. Fadhilah, H. 2018. The Influence of Professional Scepticism and Time Budget Pressure of Auditor's Ability to Detect Fraudulent Financial Reporting (Survey on Senior Auditor in Big Four Firms). International Journal of Business, Economics and Law, 16 (1), pp. 5358.

11. Faradina, H. 2016. The Influence of Workload, Audit Experience, and Personality Types on Professional Skepticism and Auditor Ability to Detect Fraud (Empirical Study of Public Accounting Firms in Medan, Padang, and Pekambaru). JOM Fekon, 3 (1), pp. 12351249.

12. Fawdy, R. M. 2017. The Influence of Workload, Audit Experience and Personality Types on Professional Skeptics and Auditors' Ability to Detect Fraud (Case Study at the Inspectorate Office of Padang City). Thesis Journal. Department of Accounting, Faculty of Economics, Andalas University. Padang.

13. Fitriyani. 2012. Comprehensive Analysis of the Effect of Competence and Independence of Public Accountants on Audit Quality. Dissertation of the University of Indonesia.

14. Fullerton, R. R., and Durtschi, C. 2004. The Effect of Professional Skepticism on the Fraud Detection Skills of Internal Auditors. Utah State University.

15. Gusti, M. and Ali, S. 2008. The Relationship between Auditor Professional Skepticism and Audit Situation, Ethics, Experience and Audit Expertise with the Accuracy of Providing Auditor Opinion by Public Accountants. Padang: National Symposium on Accounting XI.

16. Hartan, T. H. 2016. Effect of professional skepticism, independence and competence on the ability of auditors to detect fraud (Empirical Study at the Inspectorate of Yogyakarta Special Region). Thesis. Yogyakarta State University.

17. Hasanah, S. 2010. The Effect of the Application of Ethics, Experience, and Professional Skepticism of Auditors on Fraud Detection. UIN Syarif Hiddayatullah.

18. Hurt, R. K. 2010. Development of A Scale to Measure Professional Scepticism. A Journal of Practice \& Theory, 29 (1), pp. 149-171.

19. Idawati, W. 2018. The Auditor's Ability to Detect Fraud: Gender, Professional Skepticism, and Time Budget Pressure. Avances in Economics, Business and Management Rersearch, 73, pp. 14-16.

20. Indrawawti, L., Cahyono D., and Maharani A. 2019. The Influence of Professional Skeptism, Auditor Independence and Fraud Audit Training on Auditor Ability to Detect Fraud. International Journal of Social Science and Business, 3 (4), pp. 393-402.

21. Indonesian Government Internal Auditor Association, 2013. Government Internal Audit Standards.

22. Januarti, I. 2011. Analysis of the Effect of Auditor's Experience, Professional Commitment, Ethical Orientation, and Organizational Ethical Values on Ethical Perceptions and Considerations. Paper presented at the National Symposium on Accounting XIV, Aceh. 
23. Jogiyanto, H. 2007. Portfolio Theory and Investment Analysis, 5th Edition, Yogyakarta: BPFE.

24. Karyono, 2013. Forensic Fraud. Yogyakarta: CV. Andi.

25. Khomsiyah, Wilson, J. and Mulyani, S. D. 2019. Auditor's Ability in Detecting Fraud. Option, 35 (21), pp. 2337-2365.

26. Koroy, T.R. 2009. Fraud Detection (Fraud) of Financial Statements by External Auditors. Journal of Accounting and Finance, 10 (01), pp. 22-33.

27. Kurnia, V. 2010. The Influence of Professional Commitment, Experience, Locus of Control, Ethics, and Audit Risk on Professional Skeptics of Public Accountants at Public Accounting Firms in Semarang. Soegijapranata Catholic University.

28. Kushasyandita, R. and Januarti, I. 2012. The Influence of Experience, Expertise, Audit Situation, Ethics, and Gender on the Accuracy of Providing Auditors' Opinions through Auditor's Professional Skeptics (Case Study at Big Four KAP in Jakarta). Doctoral Dissertation. Diponegoro University.

29. Larasati, D. and Puspitasari, W. 2019. The Influence of Auditor's Experience, Independence, Professional Skepticism, Ethical Application, and Workload on the Auditor's Ability to Detect Fraud. Trisakti Accounting Journal, 6 (1), pp. 31-42.

30. Lopez, D. M. and Peters, G. F. 2011. The Effect of Workload Compression on Audit Quality.

31. Luft, J. L. and Shields, M. D. 2001. Why Does Fixation Persist? Experimental Evidence on The Judgment Performance Effects of Expensing Intangibles. The Accounting Review, 76 (4), pp. 561-587.

32. May, G. Y. 2010. Factors That Impact on Internal Aiditors Fraud Detection Capabilities A Report for The Institute of Internal Auditors Australia. Center for Business Forensics HELP University Malaysia.

33. Molina and Safitri. 2018. Effect of Experience, Workload and Time Pressure on The Auditor's Ability to Detect Fraud. Journal of Accounting Science. 16 (2).

34. Munandar. 2010. Stress and occupational safety, Industrial and organizational psychology. Jakarta: University of Indonesia.

35. Mulyadi. 2016. Accounting Information Systems. Jakarta: Salemba Empat.

36. Muskamal, 2010. Analysis of Workload of Local Government Organizations. PKP2A II. LAN Makassar.

37. Nasution, Hafifah and Fitriany. 2012. The Influence of Workload, Audit Experience and Personality Types on Professional Skepticism and Auditor Ability to Detect Fraud. Journal and Proceedings of the National Accounting Symposium, Vol. 15.

38. Novanda, F.B.A.K. 2012. The Influence of Auditor Professionalism, Professional Ethics, and Auditor Experience on Consideration of Materiality Level. Indonesian Accounting Education Study, 1 (3).

39. Novita, U. 2015. The Effect of Experience, Workload, and Training on Scepticism and Auditor's Ability to Detect Fraud (Empirical Study at the Auditor in The Representative Office of Riau Province BPKP). JOM Fekon, 2 (1).

40. Noviyanti, S. 2008. Professional Skepticism of Auditors in Detecting Fraud. Indonesian Journal of Accounting and Finance, 5 (1), pp. 102-125.

41. Pranoto, L. H. and Retnowati, 2015. Analysis of the Company's Human Resources Workload. Jakarta: PPM.

42. Prasetyo, S. 2015. The Influence of Red Flags, Professional Skepticism, Competence, Independence and Professionalism on the Auditor's Ability to Detect Fraud (Empirical Study of Public Accounting Firms in Pekanbaru, Padang and Medan which are Registered at IAPI 2013).

43. Rinaldi, R. 2015. Requirements to Become an Auditor https://zahiraccounting.com/id/blog/ author / randi / (10 October 2020).

44. Said, L. L. and Munandar, A. 2018. The Influence of Auditor's Professional Skepticism and Competence on Fraud Detection: The Role of Tine Budget Pressure. Indonesian Journal of Accounting and Finance, 15 (1), pp. 104-120. 
45. Sanjaya, A. 2017. The Influence of Professional Skepticism, Independence, Competence, Auditor Training, and Audit Risk on Auditor's Responsibility in Detecting Fraud. Soegijapranata Catholic University.

46. Setiawan, L. and Fitriany, F. 2011. Effect of Auditor Workload and Specialization on Audit Quality with Audit Committee Quality as Moderating Variables. Indonesian Journal of Accounting and Finance, 8 (1), pp. 36-53.

47. Sihombing, E., Erlina, Rujiman, Muda I. 2019. The Effect of Forensic Accounting, Training, Experience, Work Load and Professional Sceptic on Auditors Ability to Detect of Fraud. International Journal of Scientific \& Technology Research, 8 (08), pp. 474-480

48. Soleman, Aminah. 2011. Workload Analysis in terms of Age Factors with Recommended Weighy Limit Approach. ARIKA, 05 (2).

49. Sudarmo, 2009. Fraud Auditing. Training and Education and Training for Auditor Team Leader, Educational and Training Center for the Supervision of the Financial and Development Supervisory Agency.

50. Supriyanto. 2014. Effect Workload, Audit Experience, Personality Types and Professional Scepticism on the Auditor's Ability to Detect Fraud (Empirical Study in Public Accounting Firm in Solo and Yogyakarta) Publication Manuscript. Surakarta: Muhammadiyah University of Surakarta.

51. Suraida. 2006. The Effect of Ethics, Competence, Audit Experience and Audit Risk on the Auditor's Professional Skepticism and the Appropriateness of the Public Accountant's Opinion. Sociohumaniora, 7 (3), pp. 186-202.

52. Suryandari, N. N. A. and Yuesti A. 2017. Professional Scepticism and Auditors Ability to Detect Fraud Based on Workload and Characteristics of Auditors. Scientific Research Journal (SCIRJ), V (IX), pp. 109-115.

53. Suryanto, R., Indriyani Y., and Sofyani H. 2017. Determinants of the Auditor's Ability to Detect Fraud. Journal of Accounting and Investment, 8 (1), pp. 102-118.

54. Transparency International Indonesia. 2019. Indonesia's Corruption Index Ranking. https://www.transparency.org/en/cpi/2019/results (18 October 2020).

55. Tuanakotta, T. M. 2013. ISA-based Audit (International Standards on Auditing). Jakarta: Salemba Empat.

56. Waluyo. 2011. Indonesian Taxation. Jakarta: F Salemba Empat.

57. Widiyastuti, M., and Pamudji S. 2009. The Effect of Competence and Professionalism on the Auditor's Ability to Detect Fraud. Value Added, 5 (2), pp. 52-72.

58. Wiguna, F., Hapsar D.W. 2015. The Influence of Professional Skepticism and Auditor Independence on Fraud Detection (Survey on KAP Auditors in Malang).

59. Yati. 2017. The Effect of Workload, Audit Experience and Professional Skepticism on the Auditor's Ability to Detect Fraud (Case Study at a Public Accounting Firm in DIY). Repository PGRI Yogyakarta University.

60. Yulia, E. S. and Nayang, H. 2018. The Influence of Workload, Experience, and Professional Skepticism on the Auditor's Ability to Detect Fraud (Empirical Study at BPK RI Representative of West Sumatra Province). WRA Journal, 6 (1), pp. 1173-1192. 